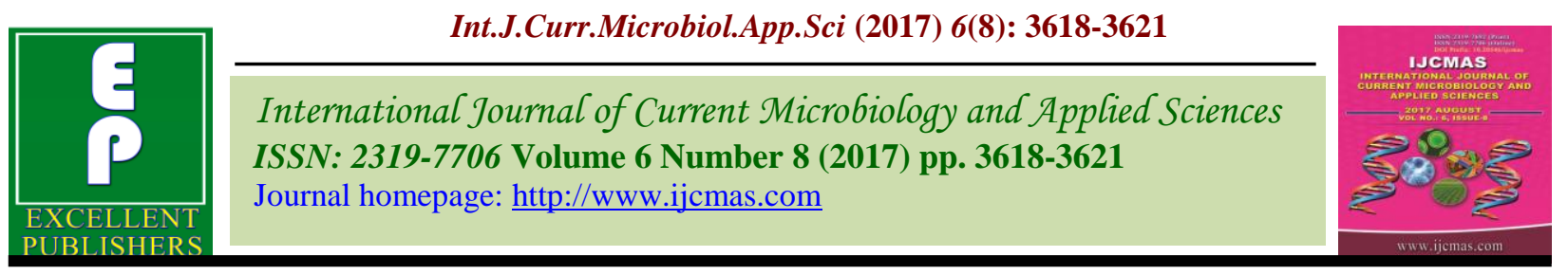

Case Study

https://doi.org/10.20546/ijcmas.2017.608.435

\title{
Flower Cultivation: A Case Study of Farmer's Family in Himachal Pradesh, India
}

\author{
Arvind Bijalwan*, Sharda Dubey and Satendra Kumar Rathaude \\ Indian Institute of Forest Management, P.O. Box- 357, Nehru Nagar, \\ Bhopal-462003, M.P., India \\ *Corresponding author
}

\begin{tabular}{|c|c|}
\hline & A B S T R A C T \\
\hline \multirow[b]{2}{*}{$\begin{array}{l}\text { K e y w o r d s } \\
\text { Floriculture, } \\
\text { Traditional } \\
\text { agriculture, } \\
\text { Carnation. }\end{array}$} & \multirow{4}{*}{$\begin{array}{l}\text { Flower cultivation is considered to be lucrative and high returned agri- } \\
\text { business. The present case was documented for a flower cultivating family } \\
\text { (Thakur family) in Mahog village of Solan district of Himachal Pradesh, } \\
\text { India. The observation revealed that flower cultivation is a profitable } \\
\text { business but contains challenges in many respects. The flower cultivation } \\
\text { family considers that there is a need to diversify the flower business to Eco- } \\
\text { floriculture for secure and sustainable future. }\end{array}$} \\
\hline & \\
\hline Article Info & \\
\hline $\begin{array}{l}\text { Accepted: } \\
\text { 27 June } 2017 \\
\text { Available Online: } \\
10 \text { August } 2017\end{array}$ & \\
\hline
\end{tabular}

\section{Introduction}

Agricultural, an age old practices in India involved cultivation of variety of agricultural crops. As time elapsed, farmers of India moved from traditional agricultural to modern agriculture or cultivation of cash crops to increase the productivity and income from the farm land and thus rural economy transformed from crop to cash. In a study, similar scenario was observed in a progressive farm family in Mahog village of Himachal Pradesh, India, where the Thakur family is professionally involved in cultivation of variety of flowers including Carnation, Chrysanthemum, Gladiolus, Lily, etc.
The farm was visited during March, 2017, and the detailed information pertaining to methods of flower cultivation, flowering techniques, marketing approach and income generation were done. During visit, we met to Mr. Babu Ram Thakur, head of flower cultivation family and all his family members. It is worth mentioning here that family members are participating in flower cultivation and every member has given a specific role to contribute in flower cultivation, management and marketing. While taking to one of the prominent member of his family Mr. Kuldeep Singh Thakur alias Dimple (people locally called him Doctor of flower), he narrated the entire story and different dimensions of flower cultivation including challenges, 
opportunities and future strategy of flower business. Mr. Dimple said, initially about 25 years ago, when our senior family members started flower cultivation it was considered as a unique business in this area, however now flower businesses has taken different dimensions in all respects. He said our forefathers' used to cultivate traditional crops such as wheat, maize, oat etc which is now shifted to cash crop viz potato, tomato beans, capsicum, cauliflowers, and other vegetables to flower cultivation. The present generation is more concerned toward money fetching crops and therefore, flower cultivation seems to be a high paying and lucrative business. It is fact that flowering business comparatively gives more return but has increasing compound challenges too. If we see, at present around 2500 farmers are involved in flower cultivation in 584 hectares of land in Himachal Pradesh, the total earning from floriculture in Himachal Pradesh around Rs. 220 million a year (De and Singh, 2016).

Thakur family is mainly cultivating the cut flowers, particularly carnation. While doing cultivation of carnation one should be technically sound, practically knowledgeable and well equipped with market linkages. The procurement of quality planting material for carnation is also a challenge which they procure from Pune and Bangalore in the forms of bulbs and then cultivate it in captive condition i.e. inside the poly house throughout the years. The net profit earned by Thakur family from carnation cultivation is Rs. 6 lakh per annum from 1000 sqm of poly house in the first year. As the carnation crop can be continued for a period of 3 years, therefore, Rs. 6 lakh and Rs. 6 to 7 lakh can be earned in $2^{\text {nd }}$ and $3^{\text {rd }}$ years respectively. At present, Thakur family in Mahog has got about 8000 sqm area under poly house for flower cultivation and earning about 40-50 lakh/ annum from flower cultivation (Figures 1 to 6$)$.

The carnation flower requires series of technical operation right from procurement of planting material to final harvest and marketing. It is always important to know about the superior quality of planting material which gives the flowers of F1 grades (in general flower grades varies from F1 to F7). It is advised that one plant should be expected to use for 35 flush (35 flowers) as 35 flowers of F1 category (good quality) can only be obtained from a carnation plant. However, it was noticed that flower cultivating farmers in other part taking 100 to 200 flush of inferior category which ultimately also deteriorate the quality of flowers. Obtaining genetically superior planting material also a big challenge before farmers, moreover sowing, weeding, growing thinning, maintaining moisture and temperature during the carnation cultivation is also need to be consider as one of the important technical aspects. In Indian floriculture the major constrains such as lack of reliable database in floriculture, unavailability of quality seed and planting material of flowers and lack of adequate infrastructure for quick disposal of flower to the markets (De and Singh, 2016).

Though the carnation flower grows across the season but it remain dormant in flowering during winter season and flowers beautifully during April to August. Application of fertilizer, pesticides and insecticides are important management aspects need to be considered for better and quality flowers. The harvesting, storage and packing are important aspects to maintain the shelf life of flower; moreover, adoption of proper transportation to the market is also important to maintain the quality of freshness of flower.

Photographs of floriculture cultivation by Thakur's family at Mahog, Shimala, Himachal Pradesh, India 


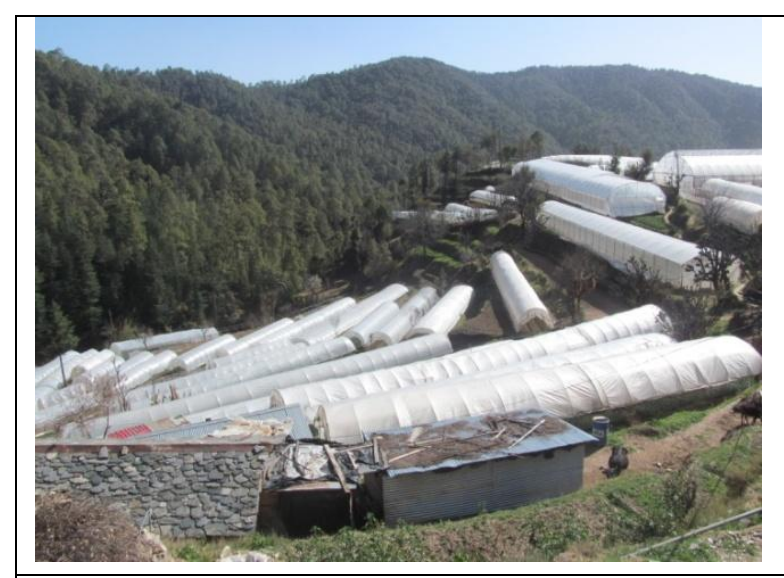

Fig.1 Floriculture field of Thakur Family, Mahog, Shimal

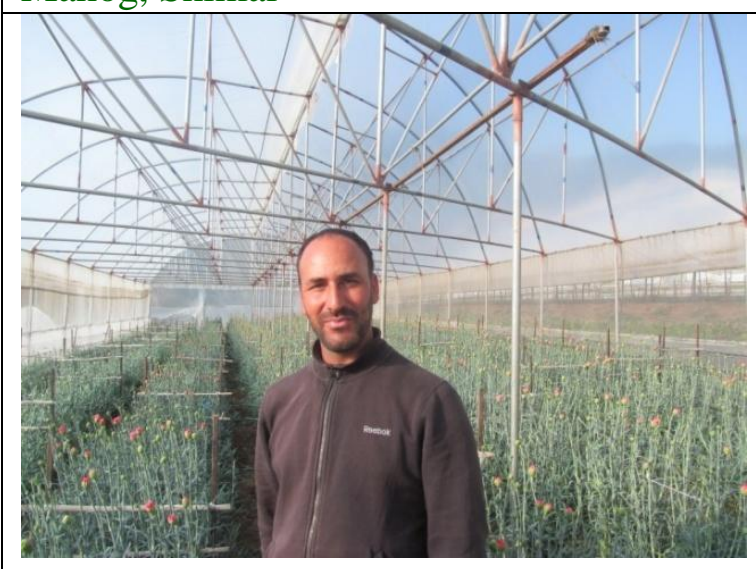

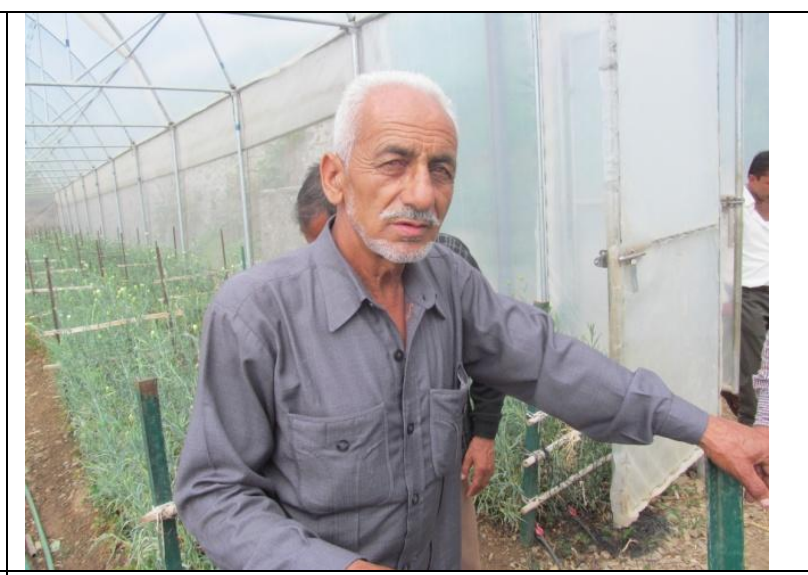

Fig.2 Mr. Babu Ram Thakur, Head of the Family

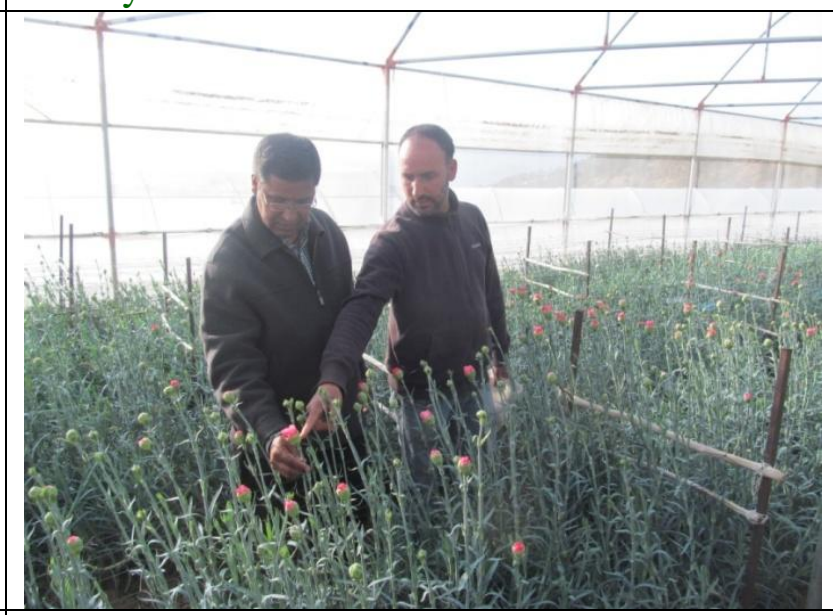

Fig.4 Kuldeep Singh Thakur alias Dimple showing the tips of Carnation cultivation

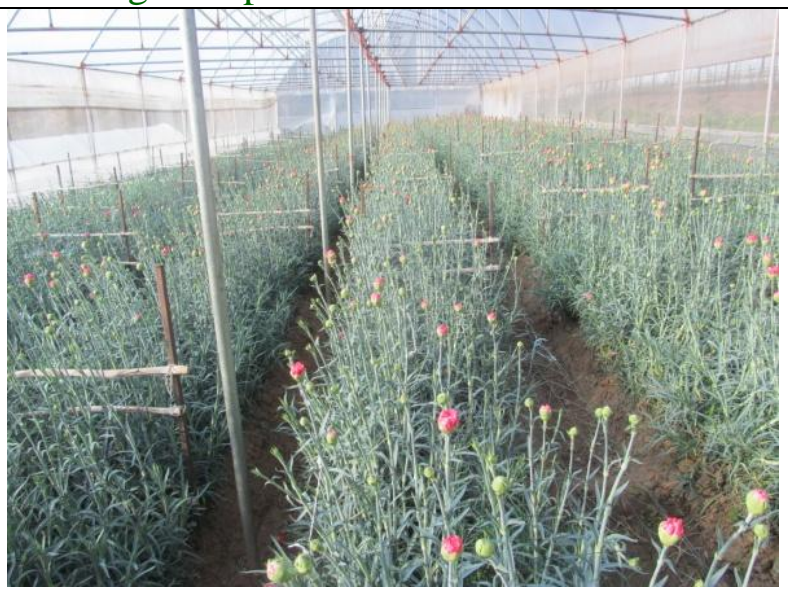

Fig.6 A panoramic view of cultivation of Carnation under Poly house

harvested in semi blossom (not full matured) stage so that it can be attain more shelf life.
It is also important to take care during the harvest of flower as the flowers need to be 
In present days, subsidy on poly house construction is being provided by the government to the interested farmers to encourage the cultivation of vegetables, flowers etc inside the poly house. The subsidy given by Himachal Pradesh horticultural and agricultural department based on the land holding of the farmers. The government is prompt enough to encourage the farmers for poly house construction by providing subsidy to a very high level to support the farmer but there are many farmers taking subsidy just for the sake that they are getting high subsidy on it. In floricultural sector timely availability of suitable market is an important task to be finalized before starting flowers business. Since it is perishable item therefore every care should be taken to minimize the loss of flower, thus for this purpose precision post harvest management, cold storage and suitable air conditioner transportation vehicle should be timely arranged. In flowering sector grading and packing plays crucial role, therefore timely harvesting is important indication of good business. While doing the grading it is important to note that the quality being properly controlled before its final packing so as to maintain flowers remain fresh and turgid. $\mathrm{Mr}$ Kuldeep Singh Thakur allies Dimple said that being low landholder and limitation of technology and further expansion, we are at present in the apex of this business particularly in this area and there are no further possibilities to grow this business with limited resource and technology. Therefore, they have decided for diversification of floriculture business to a "Eco-floricultural" business where they are planning to include floriculture for ecological, aesthetic and economic view points. For establishing the eco-floricultural on flower farm, Thakur family is also constricting some cottages in the flower farm making natural trail for walking, constructing some eco and green hotels so that the tourist can be attracted and flower business can be diversified to take a new dimension.

\section{Acknowledgement}

The author is thankful to the Director, Indian Institute of Forest Management, Bhopal for his support and encouragement to undertake this study. The author is also thankful to International Papers, Hyderabad via IP-IIFM Paul Brown Centre of Excellence for providing the financial assistant to conduct the study "Community Livelihood promotion through assessment of Biodiversity and Carbon Sequestration potential in Agroforestry systems along altitude and aspects of Western Himalaya. This study was documented while doing the agroforestry survey for the above project. Special thanks to Mr. Babu Ram Thakur and Mr. Kuldeep Singh Thakur along with other members of Thakur family for providing the technical inputs of flower cultivation and their flower enterprise. The forest department of Chail, Solan Forest Division, Solan, HP is extremely acknowledged for support during the field survey.

\section{References}

De, L.C. and Singh, D.R. 2016. Floriculture Industries, Opportunities and Challenges in Indian Hills. Int. J. Horticul., 6(13): 19.

\section{How to cite this article:}

Arvind Bijalwan, Sharda Dubey and Satendra Kumar Rathaude. 2017. Flower Cultivation: A Case Study of Farmer's Family in Himachal Pradesh, India. Int.J.Curr.Microbiol.App.Sci. 6(8): 3618-3621. doi: https://doi.org/10.20546/ijcmas.2017.608.435 